\title{
Bioassay of the Ultrastructural characteristics in the kidney and liver of the African catfish, Clariasgariepinus juveniles exposed to graded concentration of zinc
}

\author{
Akaahan T . J. ${ }^{1}$, Akogwu S.A. ${ }^{2}$, Olabanji F . M. ${ }^{3}$ \\ ${ }^{1}$ Environmental Science and Zoology Unit Department of Biological Sciences University of Agriculture, P.M.B. 2373 Makuedi \\ Benue state Nigeria. \\ ${ }^{2}$ Department of Biological Sciences Federal University P.M. B. 1005, GashuaYobestate Nigeria. \\ ${ }^{3}$ Department of Environmental Biotechnology, National Biotechnology Agency Abuja Nigeria.
}

\begin{abstract}
Bioassay in the structural deformation of the kidney and the liver of African catfish, Clariasgareipinus exposed to graded concentration of zinc was determine for a period of 96 hours. The stock solution was prepared with zinc and the fish juveniles were exposed to the following concentration in $\mathrm{mg} / \mathrm{L}: 0.5,0.75 .1 .00,1.25$ and 1.50 with a control of $0.0 \mathrm{mg} / \mathrm{L}$ where the zinc was not introduced. The kidney and the liver of the dead fish were dissected and subjected to histology test.The regression plot of the probit value transformed mortality against the concentration of zinc showed a strong relationship with the death of the fish exposed to the concentration of the metal with $R^{2}$ value of 0.8725 . Similarly the regression plot of the percentage mortality of the fish juveniles with zinc concentration indicate a very strong relationship with the toxicity of the metal that results to death of the fish at varied concentration with a $R^{2}$ value of 0.99754. All the same probit transformed mortality and the log transformed concentration of zinc depict a very weak relationship between zinc toxicity and the lethality of the fish with a very low $R^{2}$ value of 0.0873. All the same no death was observed in the control throughout the 96 hours period of the study while the lowest death of $15 \%$ was recorded in the $0.5 \mathrm{mg} / \mathrm{L}$ and the highest of $60 \%$ in the $1.50 \mathrm{mg} / \mathrm{L}$ concentration of zinc. The $L C_{50}$ was determined to be $1.25 \mathrm{mg} / \mathrm{L}$ during the study time. The result of the bioassay in the ultrastructural characteristics showed pathological lesion in the kidney and vacuolation of the hepatocytes of liver of the fish. The DO of the water was below the recommended level for the survival of the fish in the waters that the concentration of zinc was introduced and may cause distress to the fish. The fish showed erratic movement and distressful behavoiur
\end{abstract}

where they were exposed to zinc and eventually the ones that could not tolerate the toxicity of the metal died. The study conclude that the fish should not be exposed to the elevated concentration of zinc as it is toxic and recommend that anthropogenic activities that release zinc into the environment should be controlled.

Keywords-Bioassay, Clariasgariepinuskidney, liver Zinc.

\section{INTRODUCTION}

The second most abundant heavy metal after iron in the earth crust is zinc. It is an essential element and micro nutrient in almost all the cells of the living organisms. Zinc is a trace element which is important in the nucleic acid synthesis and it is found in many enzymes (Sfakianakis, et. al., 2015). Zinc is found in water as a free cation. $\mathrm{Zn}^{2+}$ is soluble in zinc complexes and it can be absorbed or suspendedin the water (Authmanet al., 2015). The metal and its compounds are used extensively in the manufacturing industries and in medicine (Authmanet al., 2015). Anthropogenic sources resulting from the explosion of human population with the development of science and technology have contributed to the loading of metals like zinc into the aquatic environment (Agebi and Owoeye, 2012). The water that is contaminated with heavy metals may adversely affect the immune system of the fish resulting in the decrease in production and increasing the susceptibility of the fish to disease condition that may lead to the death of the fish (Raniet al., 2015). Although small amount of zinc in the water or diet is essential to living organisms, however it is at elevated concentrations that becomes detrimental to the health condition of the fish and 
other organisms. Ultrastructural deformities are histopathological biomarkers which are sensitive indicators of subcellular stress in organisms exposed to short and long periods of graded concentrations of toxicants (Adams, et al., 2000). Fish exposed to elevated concentration of zinc may die, retard in growth, and experience respiratory and cardiac changes, inhibiting spawning and other detrimental effects that affects the fish. In addition the gills, liver, kidney and skeletal muscle may be damaged (Sorensen, 1991).

Clariassp is a species of fish that is distributed widely in Asia and African regions of the World. And the fish is common with its tasty flesh, grows very rapiadly and has a very high market value in these areas( Ovie and Oghogene, 2008). Similarly in Nigeria Clarias is an indigenous fish found in virtually all the freshwater in the country. The most common species of Clariasthat is found in Nigeria is Clariasgariepinus that is found in every fresh water in Nigerian. All the same the fish is at the risk of heavy metals exposure like zinc due to the toxicity of these metals resulting to death of the fish and threatening its population in the Nigerian freshwater ecosystems. More so, the fish is a rich source of protein and is widely consumed in Nigeria, and having its organs exposed to heavy metal may affect the health of humans that consume the fish directly and have implication for public health. The objective of this study is to determine the lethal concentration of zinc metal exposed to African catfish Clariasgariepinus and to investigate the level of damage caused in the kidney and liver of the fish exposed to the metal as the most sensitive organs of the fish.

\section{MATERIALS AND METHODS}

\section{Sample collection}

One hundred and twenty specimens of Clariasgariepinus juveniles of mean weight $21.2 \mathrm{~g}$ were obtained from the fishfarm, University of Agriculture Makurdi and were transported in large plastic bowls to the Fisheries and Aquaculture laboratory of the University of Agriculture, Makurdi, Benue State.

\section{Acclimatization of fish}

The fish were acclimatized in order to adapt to the laboratory conditions, during which time they were provided with artificial feed. The size of fish varied from $12 \mathrm{~cm}-14 \mathrm{~cm}$ in standard length and $20-22.4 \mathrm{~g}$ in weight. Fish of both sexes were used without discrimination. The fish were not fed throughout the day that they were obtained due to stress which may prevent easy digestion and cause mortality. Feeding commenced the following day in the morning, and they were fed with commercial feed (copens
$2 \mathrm{~mm}$ ) at $4 \%$ of initial body weight (Meyer et al., 1998). One hundred and twenty fish juveniles were held in a large bowl containing about 80 litres of water during acclimatization period that lasted for 14 days. The water in the bowls in which the fish were put into werechangedevery day for two weeks in order to avoid pollution by fish exudes and food remnant of the unconsumed feed and faecal were removed and water replenished.

\section{Preparation of stock and test solution of zinc metal}

The test chemical was zinc metal. The concentrations prepared for the experiment were $0.50 \mathrm{mg} / \mathrm{L}, 0.75 \mathrm{mg} / \mathrm{L}$, $1.00 \mathrm{mg} / \mathrm{L}, 1.25 \mathrm{mg} / \mathrm{L}$ and $1.5 \mathrm{mg} / \mathrm{L}$. A stock solution of zinc metal was prepared by adding $5 \mathrm{mg}$ of the toxicant to 1 litre of distilled water. The amount of zinc metal which contain $5 \mathrm{mg} / \mathrm{L}$ of zinc was determined from the molecular and atomic weight of the zinc.

\section{Determination of lethal concentration}

The toxicity test was conducted to determine the $\mathrm{LC}_{50}$ value with reference to FAO procedure for short term exposure (Reish and Oshida, 1987). The test lasted for 96 hours.

\section{Application of the Toxicant to the Fish juveniles}

The toxicity test of the acclimatized juveniles of Clariasgariepinus were carried out in two phases and each group was replicated by dividing them into 10 groups and exposing themto $96 \mathrm{hr} \mathrm{LC}_{50}$ of zinc and an unexposed group without the toxicant served as the control for four days. The bowls were covered with a mesh to prevent juveniles from jumping out of the water. Dead fishes during this period were identified by an absolute lack of movement. They were removed as soon as it was noticed and dissection was carried out by removing the kidney and the liver that were preserved in $10 \%$ formalin for preservation in order to carryout histopathological test to detect the damage caused on these organs of the fish.

\section{Histopathological Examination}

The fish in the control and the treatments were dissected and the kidney and liver were removed from the fish. They were fixed in FAA (Formaline Acetic acid Alcohol). The tissues that were fixed were processed with alcohol dehydration and tetrahydrofuran for clearing. The tissues were then embedded in paraffin wax at the congealing point of $58-60^{\circ} \mathrm{C}$ and longitudinal sections and transverse sections of serial sections of $5-8 \mu$ thickness were taken out. These sections of these tissues were stained in haemotoxylin and eosin (HE). The sections were deparaffinised through two changes of xylene each in ten minutes time. The hydrated sections were then stained with Delafield haemotoxylin for a period of five minutes and differentiated in acid alcohol by dipping and then washed in running tap water for five 
minutes. After dehydration the sections were counter stained in eosin by dipping and the excess stain was removed by placing in $90 \%$ alcohol for 30 seconds and absolute alcohol for five minutes. After then the dehydrated sections were blotted once again and cleared in two changes of xylene with the first change in ten minutes time and second change in fifteen minutes period. The sections were further blotted and mounted in DPX (Diestereneplasticizer xylene). The tissues were examined under the microscope and then micro photographed.

Determination of the physico-chemical parameter of water

Water temperature, TDS, Conductivity, $\mathrm{DO}$ and $\mathrm{pH}$ were determined in the laboratory with measuring meters.

Data Analysis

The test concentrations were converted into logarithm and the corresponding mortality percentage into the probit value (Finney 1971). The obtained probit values were plotted against the graded concentration of the zinc metal. The physico-chemical results were subjected to student $t$ test analysis and descriptive statistics.

\section{RESULTS}

Toxicity ofzinc Exposed toClariasgariepinus juveniles

The results presented in Table 1 is the 96 hours acute toxicity test of Clariasgariepinusjuveniles exposed to zinc.
A perusal at the result indicate that that there was no dead fish in the control experimental set throughout the 96 hours period of the study. All the same the lowest mortality percentage of $15 \%$ was observed in the $0.5 \mathrm{mg} / \mathrm{L}$ concentration and the highest percentage mortality of $60 \%$ was in the $1.25 \mathrm{mg} / \mathrm{L}$ concentration of zinc. The $\mathrm{LC}_{50}$ was determined to be $1.25 \mathrm{mg} / \mathrm{L}$ during the period of the study. It was generally observedthat the mortality of the fish increased with increase in the concentration of zinc. Similarly Figure 1 is the regression of probit mortality values and graded concentration of zinc exposed to juveniles of Clariasgariepinus. The result indicate a strong relationship between the concentration of zinc and the mortality of the fish with the $\mathrm{R}^{2}$ valueof 0.8725 . Figure 2 is the result of the regression of probit values and $\log$ of graded concentration of zinc exposed to juveniles of Clariasgariepinus. The result showed that there is very weak relationship between the log of concentration and the mortality of the fish with a $\mathrm{R}^{2}$ value of 0.0873 . The data in Figure 3 is the regression of percentage mortality values and concentration of zinc exposed to juveniles of Clariasgariepinus. The result indicate that there is there is a very strong relationship between the concentration of the zinc and death of the fish with $\mathrm{R}^{2}$ value of 0.9754 .

Table.1: 96 hours acute toxicity test of Clariasgariepinus juveniles exposed to zinc.

\begin{tabular}{lllllll}
\hline s/n & $\begin{array}{l}\text { Concentration } \\
(\mathbf{m g} / \mathbf{L})\end{array}$ & $\begin{array}{l}\text { Log of } \\
\text { concentration }\end{array}$ & $\begin{array}{l}\text { Number } \\
\text { of fish } \\
\text { exposed }\end{array}$ & $\begin{array}{l}\text { Number } \\
\text { of fish } \\
\text { died }\end{array}$ & Mortality & $\begin{array}{l}\text { Probit } \\
\text { Value }\end{array}$ \\
\hline 1 & 0.00 & 0.000 & 20 & 0 & 0 & 0.00 \\
2 & 0.5 & -0.301 & 20 & 3 & 15 & 3.30 \\
3 & 0.75 & -0.125 & 20 & 5 & 25 & 3.96 \\
4 & 1.00 & 0.000 & 20 & 9 & 45 & 4.87 \\
5 & 1.25 & 0.097 & 20 & 10 & 50 & 5.00 \\
6 & 1.50 & 0.176 & 20 & 12 & 60 & 5.25 \\
\hline
\end{tabular}

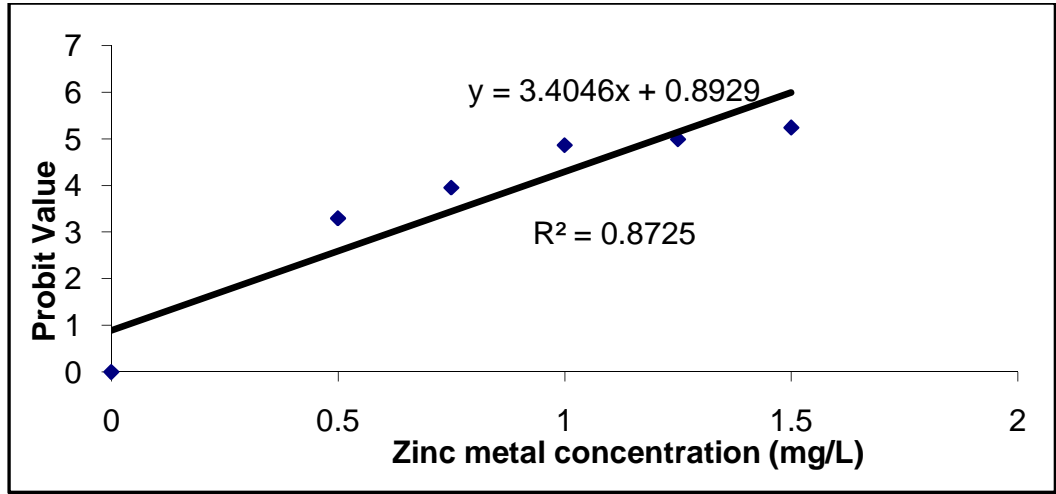

Fig.1: Regression of Probit mortality values and graded concentration of zinc exposed to juveniles of Clariasgariepinus. 


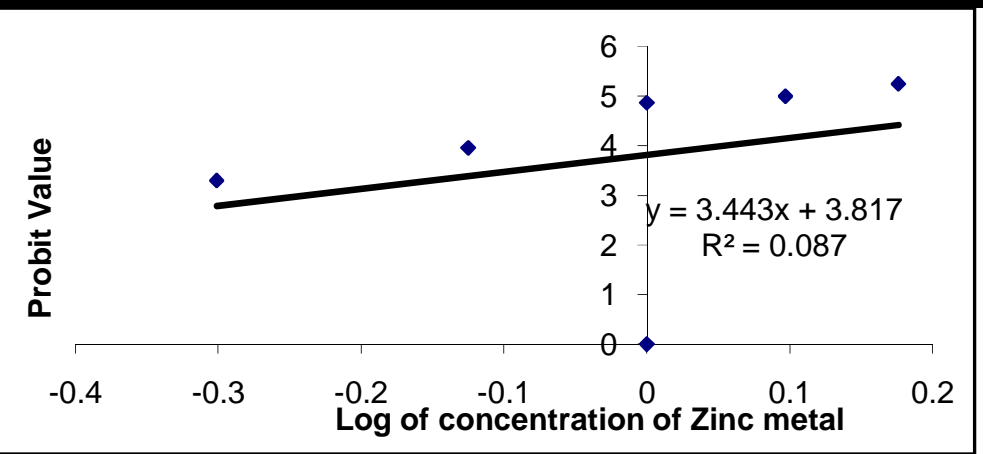

Fig.2: Regression of Probit mortality values and log of graded concentration of zinc exposed to juveniles of Clariasgariepinus

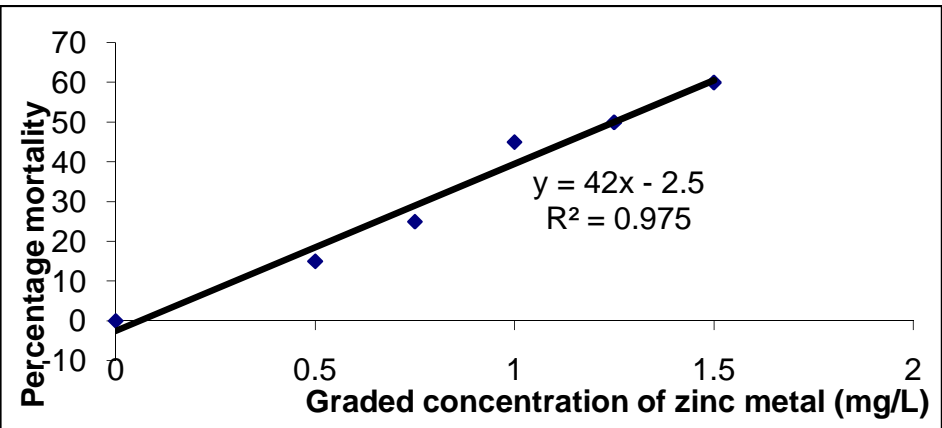

Fig.3: Regression of percentage mortality values and graded concentration of zinc exposed to juveniles of Clariasgariepinus

The results in Plates 1-12 indicate the histopathological analysis of the kidney and liver of Clariasgariepinus. The control has no pathological lesions in the kidney (plate 1), but the exposed concentrations shows significant indication of toxicity of zinc in the kidney of Clariasgariepinus. Plate 2-6 shows how the kidney cells were observed to have been massively destroyed showing karyolysis of nucleic materials, vacuole formation of the tubular epithelial cells, necrosis and the renal corpuscle of the kidney were scattered resulting in their disorganization and consequently obstruction to their physiological functions. Plates 8-12 is the alterations on the liver of Clariasgariepinus exposed to different concentrations of zinc leading to the inflammation of the liver cells, diffused vacuolation of hepatocyte, hepatic cell rupture,fatty infiltration and vacuole formation. The liver of some portions of the liver tissue that were observed probably resulted from the excessive work required by the fish to get rid of toxicant from it body during the process of detoxification by the liver. The inability of the fish to regenerate new cells may also lead to severe cell rupture of the hepatic cells while Plate 7 shows normal liver ofClariasgariepinus.

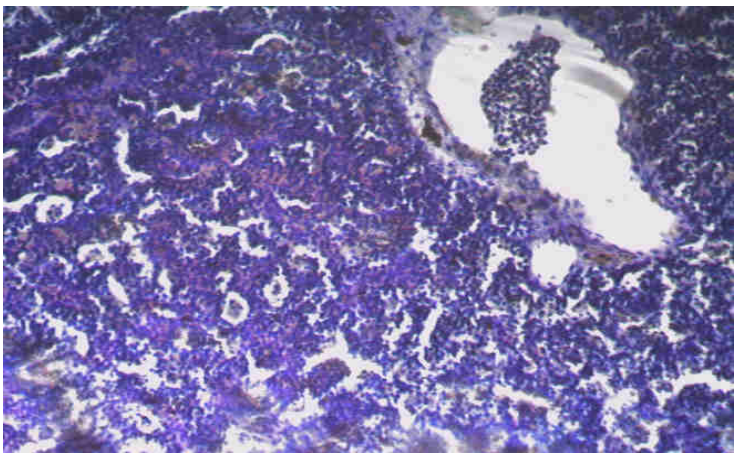

Plate 1. Kidney of Clariasgariepinus in control bowl shows no pathological lesions. X10

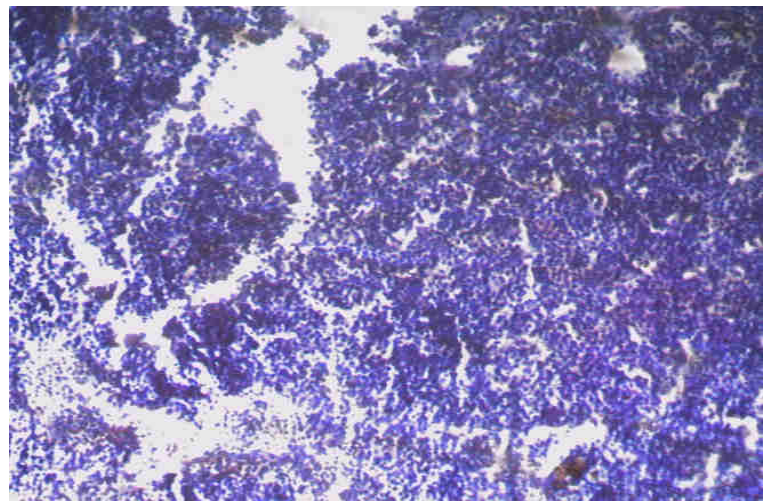

Plate 2. Kidney of Clariasgariepinus exposed to $0.50 \mathrm{~g} / \mathrm{l}$ of zinc shows karyolysis of nucleic material. X10 


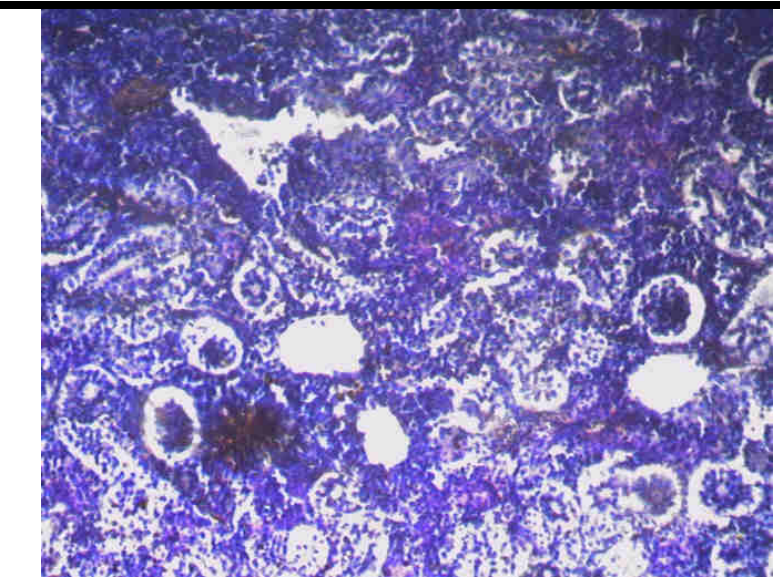

Plate 3. Kidney of Clariasgariepinusexposed to $0.75 \mathrm{~g} /$ of zinc karyolysis of nucleic material. X10

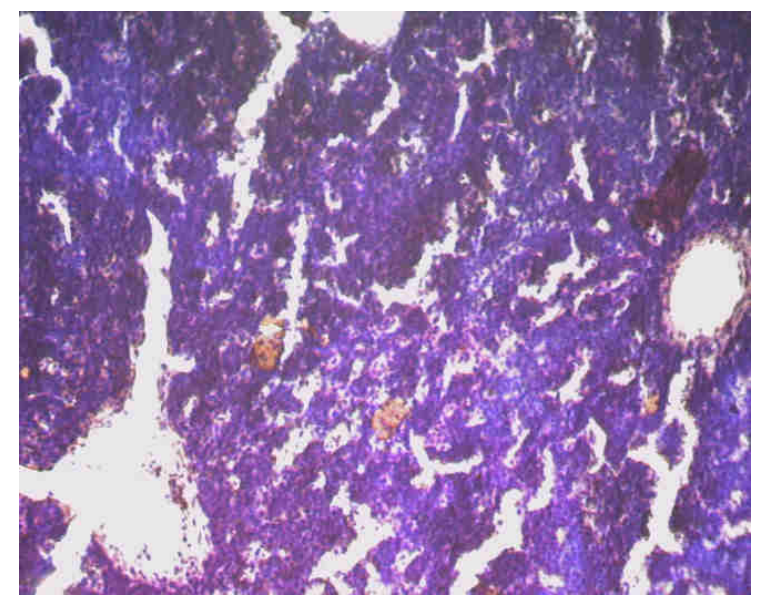

Plate 4. Kidney ofClariasgariepinus exposed to $1.00 \mathrm{~g} / \mathrm{l}$ of zinc shows vacuole formation of the tubular epithelial cells. X10

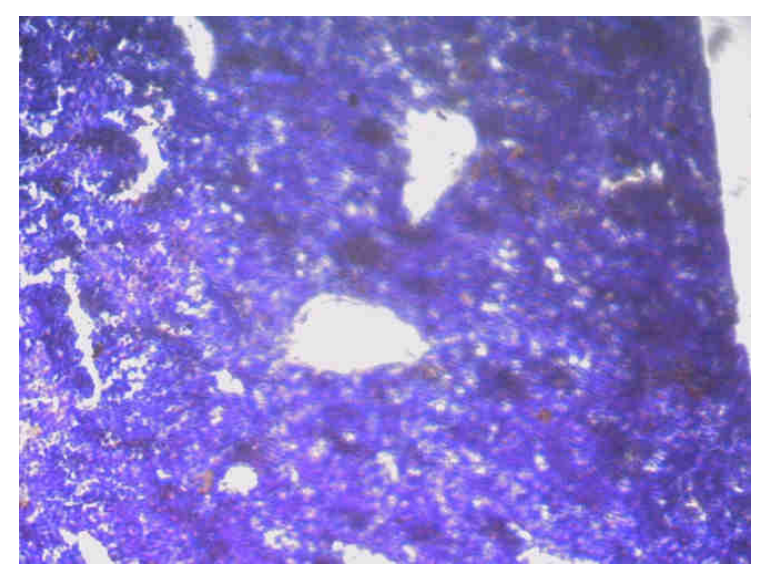

Plate 5. Kidney of Clariasgariepinus exposed to

$1.25 \mathrm{~g} / \mathrm{l}$ of zinc evidence of tubular necrosis. $x 10$

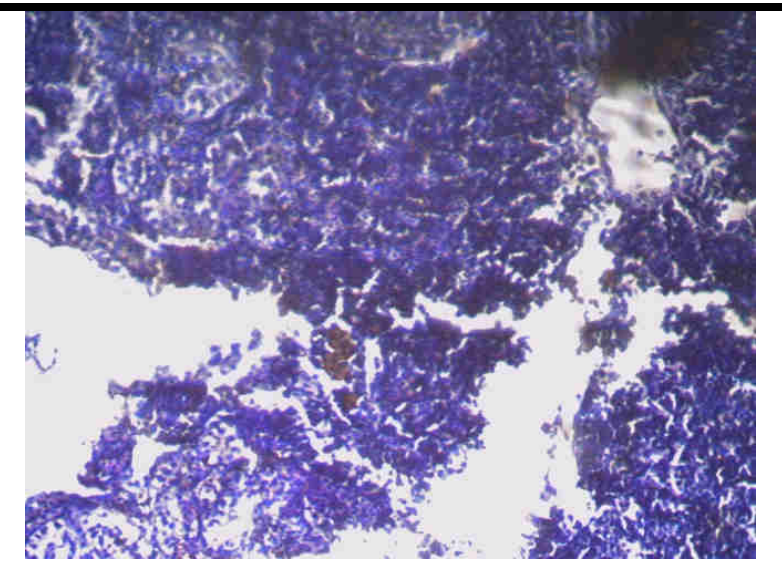

Plate 6. Kidney of Clariasgariepinusexposed to $1.5 \mathrm{~g} / \mathrm{l}$ of zinc shows tubular necrosis visible the renal tubules were dilated.

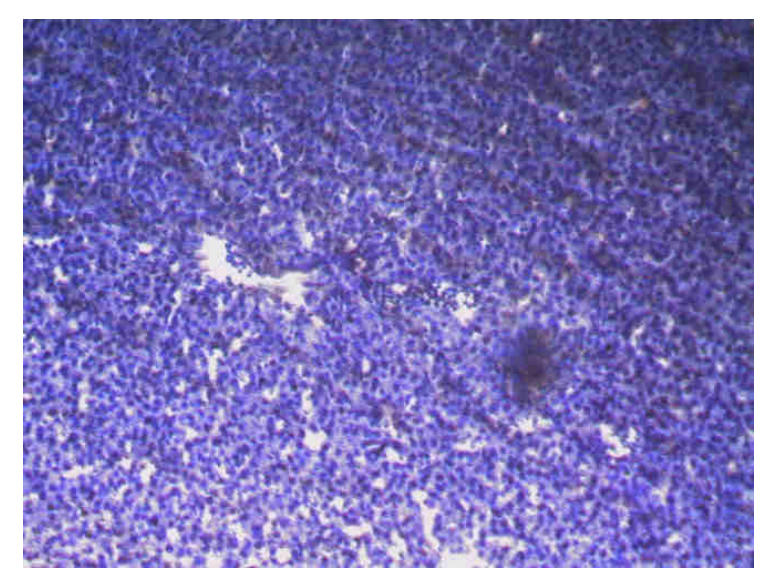

Plate 7. Liver of Clariasgariepinusin the control bowl shows no pathological lesion. X10

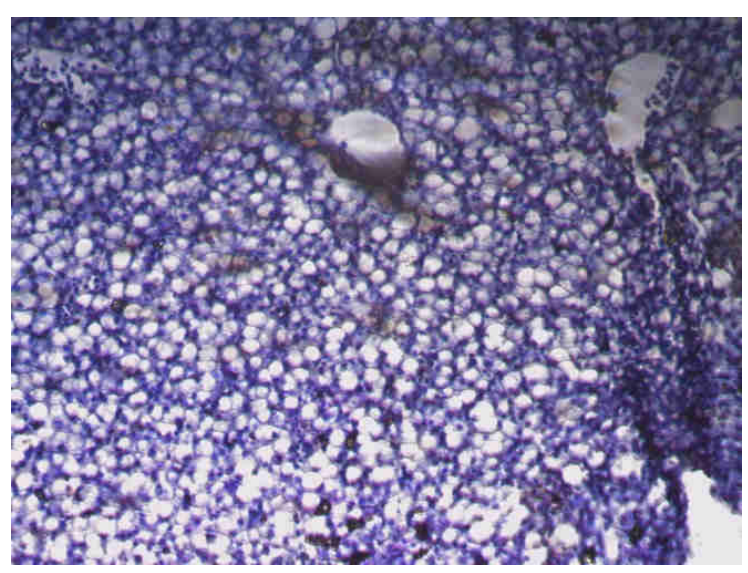

Plate 8. Liver of Clariasgariepinus exposed to $0.50 \mathrm{~g} / \mathrm{l}$ of zinc shows inflammation of the liver cells. X10 


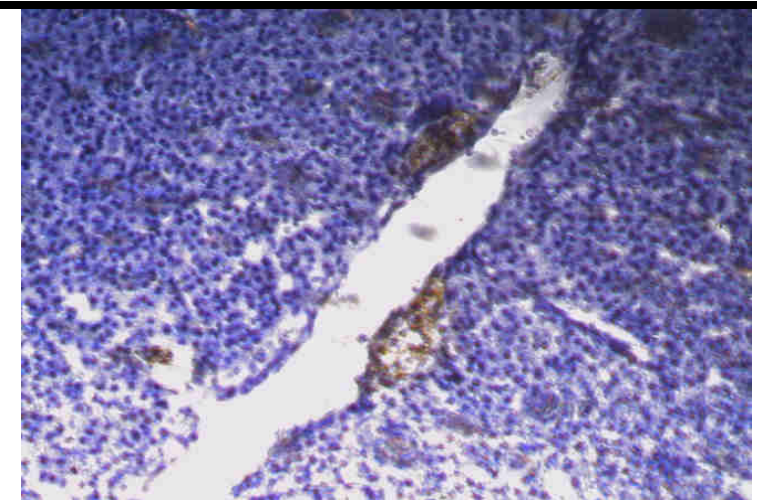

Plate 9. Liver ofClariasgariepinus exposed to $0.75 \mathrm{~g} / \mathrm{l}$ of zinc shows mild diffuse vacuolation of hepatocytes. X10

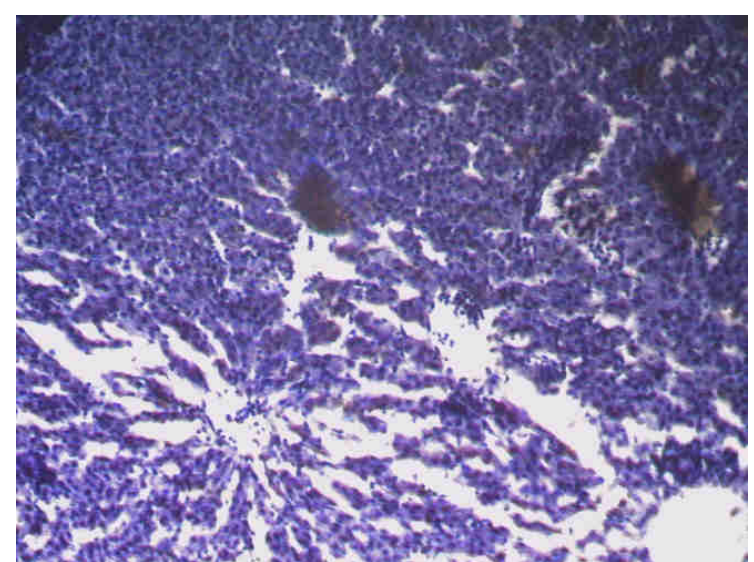

Plate 10 . Liver of Clariasgariepinus exposed to $1.00 \mathrm{~g} / \mathrm{l}$ of zinc shows severe diffused vacuolation of hepatocytes. X10

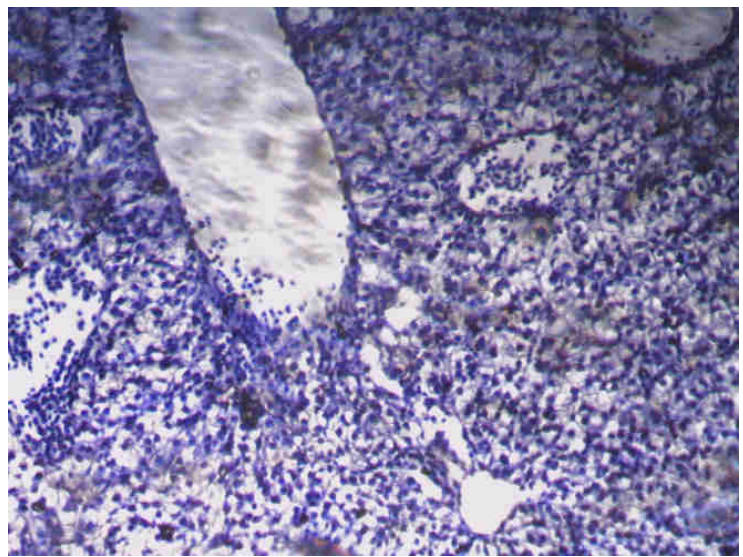

Plate 11. Liver of Clariasgariepinus exposed to $1.25 \mathrm{~g} / \mathrm{l}$ of zinc shows hepatic cell rupture of sinusoids with hemorrhages at several points. formation. X10

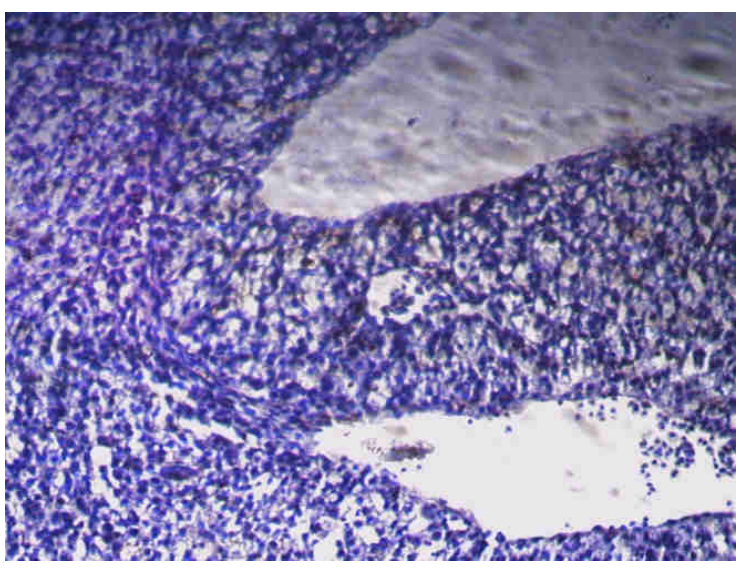

Plate 12. Liver of Clariasgariepinusexposed to $1.50 \mathrm{~g} / \mathrm{l}$ of zinc shows fatty infiltration and Vacuole formation X10

Physico- chemical Characteristics of Zinc treatments and control

The results in Table 2 is the physico-chemical characteristics of the graded concentration of zinc treatments and control experimental set up exposed to juveniles of Calriasgariepinus for a period of 96 hours. The result showed that $\mathrm{pH}$ ranged from $8.10-8.70$ with a mean of $8.42 \pm 0.22$, water temperature varied from $28.30-28.90^{\circ} \mathrm{C}$ and mean of $28.66 \pm 0.21^{\circ} \mathrm{C}$. The TDS of the water samples differed from $402.00-432.00 \mathrm{mg} / \mathrm{L}$ with a mean of $419.77 \pm 11.43 \mathrm{mg} / \mathrm{L}$, EC ranged from $805.00-862.00 \mu \mathrm{S} / \mathrm{cm}$ with mean of $839.00 \pm 22,31 \mu \mathrm{S} / \mathrm{cm}$. The DO of the water samples varied from $4.29-4.82 \mathrm{mg} / \mathrm{L}$ with a mean of $4.58 \pm 0.21 \mathrm{mg} / \mathrm{L}$. The $\mathrm{t}$ test was significant across all the examined parameters $(\mathrm{P}<0.005)$.

Table.2:Physico-chemical characteristics of graded concentration of zinc treatments and control exposed to JuvenilesClariasgariepinus for 96 hrs,

\begin{tabular}{llllll}
\hline $\begin{array}{l}\text { Concentration } \\
(\mathbf{m g} / \mathbf{L})\end{array}$ & $\mathbf{p H}$ & $\begin{array}{l}\text { Temperature } \\
\left({ }^{\mathbf{0}} \mathrm{C}\right)\end{array}$ & $\mathbf{T D S}(\mathrm{mg} / \mathbf{L})$ & $\mathbf{E C}(\boldsymbol{\mu S} / \mathbf{c m})$ & $\mathbf{D O}(\mathbf{m g} / \mathbf{L})$ \\
\hline 0.00 & 8.10 & 28.75 & 402.00 & 805.00 & 4.82 \\
\hline
\end{tabular}




$\begin{array}{lll}0.50 & 8.27 & 28.55 \\ 0.75 & 8.35 & 28.30 \\ 1.00 & 8.50 & 28.90 \\ 1.25 & 8.61 & 28.65 \\ 1.50 & 8.70 & 28.80 \\ \text { Mean } & \mathbf{8 . 4 2} & \mathbf{2 8 . 6 6} \\ \text { Std,Error } & \mathbf{0 . 0 9} & \mathbf{0 . 0 8} \\ \text { Std. Deviation } & \mathbf{0 . 2 2} & \mathbf{0 . 2 1} \\ \text { Maximum } & \mathbf{8 . 7 0} & \mathbf{2 8 . 9 0} \\ \text { Minimum } & \mathbf{8 . 1 0} & \mathbf{2 8 . 3 0} \\ \text { t. test } & \mathbf{9 2 . 1 3} & \mathbf{3 2 9 . 2 7} \\ \text { P- value } & \mathbf{0} & \mathbf{0}\end{array}$

\section{DISCUSSION}

In the course of this study Clariasgariepinus showed distressed behaviour as a result of the effect of zinc concentration exposed to the fish compared to the control experimental set up where the zinc was not exposed to the fish. These behavioural response were observed in the rapid change in the in the fish reaction to erratic swimming, gasping of breath with frequent surfacing which increases with the increase in the concentration of the zinc during the course of the study. Similarly as the exposure period of the fish to the metal increases the fish were observed to be weaker with their ventral surface turned upward and the fish that could not withstand or tolerate the concentration anylonger went into coma. Nevertheless normal behaviour were noticed in the fish in the control where the toxicant (zinc) was not introduced indicating no effect of the metal. These behavioural observation during the course of this study are consistent with the earlier findings on Clariasgaripinus but with different toxicant (Dahunsi and Oranusi, 2012). The toxic stress of the metal have significant effects on the fish which may result to several physiological malfunctions in the fish (Olufayo, 2009). The fish were stressed progressively with time before death. The stressful behaviour of respiration impairment due to the toxic effect of the toxicant were in agreement to the toxic effect of herbicide that impair respiratory organs of a fish exposed to the herbicide (Aguigo, 2002). The death of the fish could either occurred by direct poisoning or indirectly by making the medium unsuitable for the survival of the fishor it may be both (Omoniyiet al., 2002, Rahamet al.,2002 Aguigo, 2002).

The result of this study showed a very weak relationship between the probit transformed mortality and the log of concentration of zinc. This findings are similar the result of an earlier study on Clriasgaripinus that indicate a weak relationship between log concentration of zinc and mortality

$\begin{array}{lll}412.00 & 824.00 & 4.80 \\ 416.00 & 833.00 & 4.62 \\ 423.00 & 851.00 & 4.52 \\ 430.00 & 859.00 & 4.42 \\ 432.00 & 862.00 & 4.29 \\ \mathbf{4 1 9 . 1 7} & \mathbf{8 3 9 . 0 0} & \mathbf{4 . 5 8} \\ \mathbf{4 . 6 6} & \mathbf{9 . 1 1} & \mathbf{0 . 0 8} \\ \mathbf{1 1 . 4 3} & \mathbf{2 2 . 3 1} & \mathbf{0 . 2 1} \\ \mathbf{4 3 2 . 0 0} & \mathbf{8 6 2 . 0 0} & \mathbf{4 . 8 2} \\ \mathbf{4 0 2 . 0 0} & \mathbf{8 0 5 . 0 0} & \mathbf{4 . 2 9} \\ \mathbf{8 9 . 8 7} & \mathbf{9 2 . 0 9} & \mathbf{5 3 . 3 6} \\ \mathbf{0} & \mathbf{0} & \mathbf{0}\end{array}$

with $\mathrm{R}^{2}$ value of 0.10 (Makondeet al., 2015). This could be that the transformation of the graded concentration of zinc to $\log$ transformation did not depicts the actual concentration of the metal, most especially in situation where low concentration values are used as obtained in the present study. The negative values of log of concentration did not show the actual concentration and the lethality of the metal. All the same the result of this present investigation differs significantly from the findings of an earlier study that reported a very strong relationship between the probit mortality and $\log$ of concentration of zinc exposed to Clariasgariepinusfor 96 hours with a $\mathrm{R}^{2}$ value of 0.998( Adebola and Kayode 2015). All the same there was a strong relation between the probit mortality and concentration of zinc and the percentage mortality and zinc concentration with $R^{2}$ values of 0.8725 and 0.9754 respectively. These results indicate clearly that there is affinity between the concentration of zinc and death of the fish.

In this study the $\mathrm{LC}_{50}$ for the 96 hours exposure of graded concentration of zinc toClariasgariepinuswas $1.25 \mathrm{mg} / \mathrm{L}$ which differs significantly from the $1.65 \mathrm{mg} / \mathrm{L}$ reported for a different species of fish exposed to zinc for 96 hours period (Meena, 2012). The difference could be in the different species and the concentration of the zinc the species were exposed to. The histopathology changes in the kidney of Clariasgariepinus are similar to the necrosis observed in the kidney ofChannapunctatus (Bloch) exposed to zinc (Gupta and Srivastava 2006). The result of nuclear degeneration, hypertrophy of hepatocytes and pyknotic nuclei damage in the liver of Clariasgariepinus exposed to zinc are similar to the findings of earlier study that reported similar liver cell damage of the test organisms exposed to zinc (Subashkumar and Selvanayagam, 2014). The liver of the fish exposed to the graded concentration of zinc was observed with slightly vacuolated cells which depicts fatty degeneration and 
necrosis of some portions of the liver tissue which probably is the resultof the excessive workdone required by the fish to eliminate and detoxify the toxicant from its bodysystem during the process of detoxification by the liver. The inability of the liver to regenerate new cells may alsoresult to necrosis.In the present study, the kidney of Clariasgariepinus exposed to zinc concentrations showed dilation of the bowman's space and accumulation of hyaline droplets in the tubular epithelial cells of the tubule. The kidney cells were observed to be massively destroyed. The renal corpuscles were scattered resulting in their disorganization and consequently obstruction to their physiological functions as was reported by (Omoniyi et al., 2002, Rahmanet al., 2002.). The death during the course of this study was observed to relate with the time the zinc remain active in the water. The result of this study indicate that the more the retention time of zinc in the water the more death of the fish. These observations are consistent with the findings of Reddy et al., (2016). The result of the water quality parameters were suitable for fish production except for the DO. The mean value of DO was not suitable for the survival. This maybe ascribed to the toxic effect of the zinc on the DO in the treatments. However the of water that was exposed to zinc sulphate for Channa punctatus with mean DO value of $6.5 \pm 0.3$ which differs significantly with the one this study( Meena, 2012). Similarly Gupta and Srivastava (2006) reported higher value of DO in the water exposed to zinc as compared to the result of this study. All the same Mabika and Barson(2013) reported lower mean value of $4.20 \mathrm{mg} / \mathrm{L}$ exposed to zinc as compared to the result of this study. The result of the conductivity of this study is differs significantly from the lower mean conductivity of $128.40 \mu \mathrm{S} / \mathrm{cm}$ as compared to the higher values obtained in this study( Mabika and Barson 2013).

\section{CONCLUSION}

The result of the study indicate clearly that elevated concentration of zinc is toxic to the Africa catfish and showed strong affinity with mortality with increase in concentration and exposure time. The toxic stress of zinc was clearly observed in the histology results of the liver and kidney of the fish exposed to zinc while such was observed in the control. The zinc showed a pronounced effect on the DO by lowering it of the test waters and equally increased the conductivity of the test water. The study recommended that the zinc should be released into the aquatic environment due to its effects on the fish.

\section{REFERENCES}

[1] Adams, S.M., Greeley, M.S. and Ryon, M.G.(2000). Evaluating effects of contaminants on fish Health at multiple levels of biological organisation extrapolating from lower to hiher levels. Human and Eco Ris. Assess.6(1): 15-22.

[2] Adebola, B.K. and Kayode, S.J.(2015). Acute toxicity and bioaccumulation patterns of lead and Zinc in Juveniles of Clriasgariepinus. J. of Env. Sci. Toxicol. and Food Technol. 9(1):42-47.

[3] Agebi, F.O. and Owoeye, O.(2012). Toxicity of copper (II) tetraoxosulphate to African catfish (Clariasgariepinus) fingerlings. Asian J. of Agricul. and Rural Develop. 2(1): 46-54.

[4] Aguigwo,J.N (2002). The toxic effect of Cymbushpesticideon growth and survival of African catfish, Clariasgariepinus (BURCHELL, 18222) J. Aquat. Sci., 17(2): 81-84.

[5] Authman, M.M.N., Mona, S.Z. ,Khallaf, E.A. and Abbas, H.H.(2015). Use of fish as bio indicator of the effects of heavy metals pollution. J. Aquac. Res. Develop. 6(4): 1-13.

[6] Dahunsi, S.O. and Oranusi, S.U.(2012). Acute toxicity of synthetic resin effluents to African Catfish Claris gariepinus( BURCHELL 1822). American Journal of Food and Nutrition 2(2): 42-46.

[7] Finney, D.J.(1971). Probit Analysis $3^{\text {rd }}$ ed. Cambridge University Press Cambridge. 20pp.

[8] Gupta, P. and Srivastava, N.(2006). Effects of sublethal concentration of zinc on histological Changes and bioaccumulation of zinc in kidney of fish Channa punctatus(Bloch). J. of Environ. Biolo. 27(2): 211-215.

[9] Mabika, N. and Barson, M. (2013). Histopathological assessment of gill pathology in two species(Clariasgariepinus and Oreochromisniloticus) from the Sanyati Basin in lake Kamba, Zimbawe. Inter. J. of Devel. and Sustain 2(2):1476-1486.

[10] Makinde, G.E.O., Olaifa, F.E. and Bajo, O.T. (2015). Acute toxicity and histopathological Changes in gill and liver of catfish(Clariasgaripinus) exposed to 2, 4D Amine( Herbex D' SI). J. of Bio. Agric. and Heal. 5(4): 145-149.

[11] Meena, T.N.(2012). Studies on impact of zinc sulphate on behavioural responses in air breathing fishChanna punctatus( Bloch). Trends in Fisheries Research 1(1): 19-21.

[12] Meyers, M.S, Johnson, L. L, Olson, O.P (1998). Histopathological hepatic lesions as biomarkers of 
chemical contaminants posure and effectsin marine bottomfish species from the north eastern and pacific coast. U.S.A. Mar. Pollut. Bull. 37: 92-113.

[13] Olufayo M.O (2009). Haematological characteristics of Clariasgariepinusjuveniles exposed to Derris root powder.Afri. J. Food, Agric. Nutri. Dev.9(3):921-933.

[14] Omoniyi, I.A., Agbon O. and Sodunke S. A (2002). Effect of lethal and sub-lethal concentrations of Tobacco (Nicotianatobaccum), leaf dust extracted on weight and haematological changes in Clariasgariepinus (Buchell 1822). J. Appli. Sc. Environ. Manage., $6: 37-41$.

[15] Ovie, K. and Oghogheme, U.E.(2008). Sub-lethal haematological effect of zinc on the fresh water fish Hetroclariassp( Osteichthyes: Clariidae). Afri. J. of Biotechnol. 7(12):2068- 2073.

[16]Rahman, M.Z, Hossain Z, Mellah and Ahmed 2002). Effect of Diazinon 60EC on Anabustestudineus, Channapunctus andBarbadesgomonotus..The ICLARM Quarterley, $25: 8-11$.

[17]Rani, S., Gupta, R.K. and Ranni, M. (2015). Heavymetal induced toxicity in fish with special reference to zinc and cadmium. Inter. J. of Fish and Aquati. Stud. 3(2):118-123.

[18] Reddy, P.P. Jagadeshwarlu, R. and Devi, G.S.(2016). Determination of lethal concentration of $\left(\mathrm{LC}_{50}\right)$ of copper to Sarotherodonmossombica. Inter. J. Fisheri and Stud. 4(1): 172-175.

[19]Reish, D.L. and Oshida, P.S.(1987). Mannual of Methods in Aquatic Environmental Research. Part 110, Short term bioassays. FAO Tech 247: 1-62.

[20] Sfakianakis, D.G., Renien. E., Kentouri,, M. and Tsatsaluis, A.M. (2015). Effect of heavy metals on fish larvae deformities. A review. Eviron. Res., 137: 246255.

[21] Sorensen, E.M.B.(1991). Metal Poisoning in Fish: Environmental and Life Sciences Associate, Boca Raton, CRC Press Inc.

[22] Subashkuma, S. and Selvanayagam, M.(2014). Zinc oxide $(\mathrm{ZnO})$ nano particles induced histopathological changes in the liver of fresh water fish Cyprinuscarpio. Cibtech Journal of Zoology 3(3): 7477. 